bioRxiv preprint doi: https://doi org/10.1101/2022.02.22.481544 this version posted February 25, 2022. The copyright holder for this preprint (which was not certified by peer review) is the author/funder, who has granted bioRxiv a license to display the preprint in perpetuity. It is made available under aCC-BY-NC-ND 4.0 International license.

\title{
Neprosin belongs to the glutamic peptidase family G3 based on in silico evidence
}

Tiew Yik Ting, Anis Baharin, Ahmad Bazli Ramzi, Chyan-Leong Ng \& Hoe-Han Goh* Institute of Systems Biology, University Kebangsaan Malaysia, 43600 UKM Bangi, Selangor,

\section{Malaysia}

*Correspondence author: Hoe-Han Goh (gohhh@ukm.edu.my). Phone number: $+60389214557$ 


\section{Abstract}

Neprosin is a novel prolyl endopeptidase (PEP) first discovered in the insectivorous tropical pitcher plants of Nepenthes species. Neprosin has two uncharacterized functional domains of neprosin activation peptide (PF14365) and neprosin domain (PF03080), which can be found in many uncharacterized plant proteases. A previous study has shown neprosin activity in hydrolyzing proline-rich gliadin, a gluten component that triggers celiac disease. In this study, an extensive in silico structure-function analysis of neprosins was conducted to investigate the catalytic mechanism of this protein family. Results from multiple sequence alignment and ConSurf showed neprosins lack the catalytic triad and motifs of common prolyl endopeptidase family S9. Protein models of neprosins from Nepenthes $\times$ ventrata $(\mathrm{NvNpr})$ and N. rafflesiana (NrNpr1) were generated using four $a b$ initio methods and comparatively assessed to get highquality models. Structural alignment of neprosin models to experimental structures in the Protein Data Bank (PDB) found a high structural similarity to glutamic peptidases. Further investigations reveal more resemblances to glutamic peptidases with low optimum $\mathrm{pH}$ that activates the enzyme via autoproteolysis for maturation. Two highly conserved glutamic acid residues, which are stable according to molecular dynamics simulation, can be found at the substrate cleft and active site corresponding to a glutamic peptidase. Protein docking demonstrated that mature neprosins bind well with potent antigen $\alpha$ I-gliadin at the putative active cleft. Taken together, neprosins represent a new member of the glutamic peptidase family G3, with a putative catalytic dyad of two glutamic acids. This study illustrates a hypothetical enzymatic mechanism of the neprosin family and demonstrates the useful application of an accurate $a b$ initio protein structure prediction in the structure-function study of a novel protein family.

Keywords: $a b$ initio protein modeling; Carnivorous plant; Glutamic peptidase; Neprosin; Prolyl endopeptidase 
bioRxiv preprint doi: https://doi.org/10.1101/2022.02.22 481544; this version posted February 25, 2022. The copyright holder for this preprint (which was not certified by peer review) is the author/funder, who has granted bioRxiv a license to display the preprint in perpetuity. It is made available under aCC-BY-NC-ND 4.0 International license.

\section{Introduction}

Proteases are a class of enzymes that catalyze proteolysis, a process that breaks down peptide bonds of protein into smaller polypeptides or amino acids. Proteases are involved in various biological processes, ranging from specific proteolysis in the living organism to unspecific proteolysis of food proteins. For instance, proteases play important roles in protein localization, modulation of protein-protein interactions, molecular signal transduction, and generation of cell information (Barrett 2001). According to the International Union of Biochemistry and Molecular Biology (IUBMB), proteases can be classified into aspartic endopeptidase, serine endopeptidase, metalloendopeptidase, and cysteine endopeptidase based on their three-dimensional (3D) structure, active amino acid composition, and catalytic mechanism (Cornish-Bowden 2014). Proteases are popular enzymes of interest as they have wide applications in many fields, such as industrial, medical, and biological studies due to their wide substrate specificity and complex functions. Proteases are found in the pitcher fluids of Nepenthes, a genus in the Nepenthaceae tropical carnivorous pitcher plant family with over 170 species that are studied to understand the physiology and mechanisms of botanical carnivory (Clarke et al. 2018).

With high-throughput technology, omics explorations have been conducted on the Nepenthes pitcher tissues and fluids for biomolecular discovery and molecular physiology studies based on transcriptomics, proteomics, and metabolomics approaches (Ravee et al. 2021; Rosli et al. 2021). Proteases in pitcher fluids have unique characteristics such as higher enzyme stability in a wider range of temperature and $\mathrm{pH}$ conditions (Ravee et al. 2018). Therefore, proteases from Nepenthes species have great potential for industrial applications. Proteases that have been reported include the aspartic proteinase nepenthesin (Amagase 1972; Amagase et al. 1969) and the prolyl endopeptidase neprosin (Lee et al. 2016). Neprosin is reported as a prolyl endopeptidase with two novel domains that have not been characterized (Lee et al. 2016). The two domains that are previously denoted as the domain of unknown function (DUF) are the 
bioRxiv preprint doi: https://doi.org/10.1101/2022.02.22.481544; this version posted February 25, 2022. The copyright holder for this preprint (which was not certified by peer review) is the author/funder, who has granted bioRxiv a license to display the preprint in perpetuity. It is made available under aCC-BY-NC-ND 4.0 International license.

neprosin activation peptide (Neprosin_AP) domain (PF14365, previously DUF4409) or neprosin_propep (IPR025521) and the neprosin domain (PF03080, previously DUF239).

Neprosin was first discovered in $N . \times$ ventrata guided by the transcriptome sequences of N. rafflesiana (Lee et al. 2016). Neprosins were subsequently profiled in N. ampullaria and $N$. rafflesiana via proteomics informed by transcriptomics study of pitchers and fluids (Wan Zakaria et al. 2016; Zulkapli et al. 2021; Zulkapli et al. 2017). Endogenous neprosins purified from the pitcher fluids of one thousand $N . \times$ ventrata pitchers showed prolyl endopeptidase activity (Rey et al. 2016). This low-weight ( $<40 \mathrm{kDa})$ neprosin preferentially cleaves at the C-terminal proline residues under acidic $(\mathrm{pH} 2-3)$ conditions and can digest protein even at low concentrations without substrate size restriction. The study demonstrated the ability of neprosin and nepenthesin from $N . \times$ ventrata in digesting gliadin, an allergenic gluten component that can trigger celiac disease (Rey et al. 2016). Neprosin has also been explored as a tool for mass spectrometry in bottom-up proteomics studies and histone mapping (Schräder et al. 2017).

Despite many pitcher fluid protein profiling experiments (Rottloff et al. 2016; Wan Zakaria et al. 2018), only a few proteases among the aspartic proteases, neprosins, cysteine proteases, and serine carboxypeptidases found in Nepenthes species have been characterized (Buch et al. 2015; Ravee et al. 2018). The low concentrations of proteases in pitcher fluids hinder large-scale protein purification for functional characterization. Rey et al. (2016) used up to 5 liters of pitcher fluids from 1,000 pitchers fed with flies for six months to obtain sufficient enzymes to study neprosin activity. To date, neprosin has not been categorized into any clan or family in the MEROPS protease database (Rawlings et al. 2018). One reason is the lack of neprosin protein structure for inference of catalytic mechanism and biological function with unknown active cleft and catalytic residues. Hence, this study aims to address this knowledge gap via extensive in silico sequence analysis, ab initio protein structure modeling, and protein docking. The high-quality protein structures shed light on the catalytic activity of neprosins via 
bioRxiv preprint doi: https://doi.org/10.1101/2022.02.22 481544: this version posted February 25, 2022. The copyright holder for this preprint (which was not certified by peer review) is the author/funder, who has granted bioRxiv a license to display the preprint in perpetuity. It is made available under aCC-BY-NC-ND 4.0 International license.

the two conserved residues of glutamic acids at the active site, which is akin to the recently reported peptidase family G3.

\section{Methods}

\subsection{Retrieval of neprosin sequences}

Nepenthes ampullaria and $N$. rafflesiana samples in this study originated from the population in Taman Negara Endau Rompin, Malaysia. N. ampullaria and N. rafflesiana samples were obtained from Nepenthes plot UKM (GPS coordinate: $\left.2^{\circ} 55^{\prime} 11.5^{\prime \prime} \mathrm{N} 101^{\circ} 47^{\prime} 01.4^{\prime \prime} \mathrm{E}\right)$. Based on $N . \times$ ventrata neprosin sequence $(\mathrm{NvNpr})$ reported by Rey et al. (2016), Basic Local Alignment Search Tool for Protein (BLASTP) was performed to identify homologous neprosin sequences of $N$. ampullaria $(\mathrm{NaNpr})$ and $N$. rafflesiana $(\mathrm{NrNpr})$ based on recent transcriptome profiling studies (Goh et al. 2020; Zulkapli et al. 2021). NaNpr amino acid sequences were retrieved from the NCBI GenBank database using the accession ID (ARA95695.1 and ARA95696.1), whereas NrNpr amino acid sequences were discovered from the transcriptome data of PacBio sequencing (Zulkapli et al. 2017).

\subsection{In silico analysis of neprosin sequences}

SignalP 4.1 (Nielsen 2017) was used to predict signal peptides of neprosin proteins. PfamScan and InterPro were used to identify the protein domains of neprosins. DiANNA 1.1 webserver was used to predict disulfide bonds in neprosin (Ferrè et al. 2006). EMBOSS Pepstats (Madeira et al. 2019) was used to predict molecular mass and isoelectric point (pI) of neprosin with default settings. BLASTP search against NCBI nr database was carried out to find amino acid sequences with high identity. Phylogenetic tree analysis with Maximum Likelihood Method (MLM) was performed for 500 bootstrap replicates using MEGAX with top 10 hits amino acids sequences from BLASTP results of neprosins from $N . \times$ ventrata $(\mathrm{NvNpr}), N$. rafflesiana $(\mathrm{NrNpr} 1$ and 
bioRxiv preprint doi: https://doi.org/10.1101/2022.02.22 481544 this version posted February 25, 2022. The copyright holder for this preprint (which was not certified by peer review) is the author/funder, who has granted bioRxiv a license to display the preprint in perpetuity. It is made available under aCC-BY-NC-ND 4.0 International license.

NrNpr2), and N. ampullaria (NaNpr1 and NaNpr2). BLASTP analysis was also performed using Dicots Plaza 5.0 against the Arabidopsis thaliana genome sequence database (Van bel et al. 2022). The conserved amino acid in neprosin was determined via multiple sequence alignment (MSA) using neprosins and their BLASTP hits against NCBI nr and Dicots Plaza 5.0 Arabidopsis thaliana genome sequence database with Clustal Omega (Madeira et al. 2019) and ConSurf (Ashkenazy et al. 2016). The workflow of in silico analysis is summarized in Fig. S1.

\subsection{Neprosin protein ab initio structural prediction}

Predict signal peptides were excluded from structure prediction. Three-dimensional structures of neprosin protein were predicted using RoseTTAFold (Baek et al. 2021) and AlphaFold2 using ColabFold in Google Colaboratory (Jumper et al. 2021; Mirdita et al. 2021). RoseTTAFold is available at Robetta server (https://robetta.bakerlab.org). The amino acid sequences of neprosin were used as the input and the RoseTTAFold option was selected with default settings before job submission for structure prediction. AlphaFold2 with MMseqs2 was accessible on Google Colab (https://colab.research.google.com/github/sokrypton/ColabFold/blob/main/AlphaFold2.ipynb).

Amino acid sequences of neprosins were input as "query_sequence" with default settings. The Protein Data Bank (PDB) files of rank 1 models of neprosins generated by RoseTTAFold and AlphaFold2 with MMseqs2 can be downloaded from Figshre (https://doi.org/10.6084/m9.figshare.19187252). Structure assessment of neprosin protein models was carried out using SWISS-MODEL (Waterhouse et al. 2018). Default values or parameters were used for all analyses unless specified otherwise. Secondary structures of predicted models were analyzed by FirstGlance in Jmol (http://firstglance.jmol.org) online server.

\subsection{Protein structure alignment}


bioRxiv preprint doi: https://doi.org/10.1101/2022.02.22 481544 this version posted February 25, 2022. The copyright holder for this preprint (which was not certified by peer review) is the author/funder, who has granted bioRxiv a license to display the preprint in perpetuity. It is made available under aCC-BY-NC-ND 4.0 International license.

The PDB files of neprosin models from AlphaFold2 with the highest quality were uploaded to the DALI server (Holm 2020) for PDB search of proteins with similar structures. mTM-align (Dong et al. 2018) was used for pairwise protein structure alignment to assess protein structural similarity. The superposition of neprosin protein models was carried out using the "Matchmaker" function in ChimeraX 1.2.5 for the visualization of protein models (Pettersen et al. 2021).

\section{5. $\quad$ Neprosin pocket prediction and protein docking with $\alpha$ I-gliadin}

The PDB files of NvNpr and NrNpr1 protein models and their mature counterparts generated using AlphaFold2 were uploaded to CASTp3.0 webserver (Tian et al. 2018) to predict binding pockets and Richard's solvent-accessible surface area and volume. The three largest pockets were selected for each model and color-coded based on Richard's solvent-accessible surface volume. For protein-substrate docking, a crystal structure of the left-handed polyproline II (PPII) helical aI-gliadin (deaminated) was used as the ligand (Kim et al. 2004). The protein model of $\alpha$ I-gliadin (PFPQPELPY) was extracted from the crystal structure of 1S9V in the PDB database. Neprosin protein models were uploaded to PatchDock webserver (Schneidman-Duhovny et al. 2005) as receptor molecules, whereas $\alpha \mathrm{I}$-gliadin was uploaded as a ligand molecule. PatchDock is based on a geometric-based molecular docking algorithm with a geometric docking score, thus a higher docking score is preferable. Protein docking models with the highest docking score were chosen for visualization and further analysis in ChimeraX.

\subsection{Molecular dynamics simulation}

Molecular dynamics (MD) simulation of the neprosin models was carried out with CABS-flex 2.0 webserver (Kuriata et al. 2018). The PDB files of neprosin models were analyzed using default settings (C-alpha distance restraints with CABS generated restraints, protein rigidity: 1.0, number of cycles: 50 , cycles between trajectory: 50 and temperature at $\mathrm{T}=1.40$, where $\mathrm{T}=1.0$ is 
bioRxiv preprint doi: https://doi.org/10.1101/2022.02.22 481544; this version posted February 25,2022 . The copyright holder for this preprint (which was not certified by peer review) is the author/funder, who has granted bioRxiv a license to display the preprint in perpetuity. It is made available under aCC-BY-NC-ND 4.0 International license.

close to the temperature of crystal (native state), $\mathrm{T}=2.0$ enables the complete unfolding of unrestrained small protein chains). Three outputs, namely models, contact maps, and fluctuation plots were generated for each neprosin. The fluctuation plot with amino acids position (X-axis) and root mean square fluctuation (RMSF) after global superposition (Y-axis) shows the stability of each amino acid according to movement distance during the MD simulation.

\section{Results and Discussion}

\subsection{Neprosin homologs are widespread in plants with unknown functions}

According to the protein families database Pfam 35.0 (Mistry et al. 2021) as of February 2022, the Neprosin_AP domain (PF14365) was present in 2,509 sequences of 129 plant species and two sequences in two bacterial species compared to the neprosin domain (PF03080), which was present in 3,373 protein sequences of 130 plant species, 41 sequences in 28 fungal species, and 50 sequences in 39 bacterial species. There are 56 sequences containing the neprosin domain in Arabidopsis thaliana, many of which are putatively annotated as carboxyl-terminal proteinase, tRNA-splicing ligase, NEP-interacting protein with unknown functions (DUF239), or uncharacterized protein. This suggests the importance of the neprosin family in diverse taxa with yet undiscovered biological functions.

\subsection{Sequence analysis of neprosins from Nepenthes species}

SignalP 4.1 predicted the presence of signal peptides in all neprosins of Nepenthes species (Fig. 1). PfamScan and InterPro detected the presence of both neprosin activation domain (PF14365/IPR025521) and neprosin domain (PF03080/IPR004314) in the neprosins. All neprosins have three disulfide bonds except NrNpr2 with two disulfide bonds. The reported NvNpr with PEP activity shared the highest sequence identity (96\%) with NrNpr1 and the lowest identity (42\%) with the longer sequence of NaNpr1. 
bioRxiv preprint doi: https://doi.org/10.1101/2022.02.22.481544; this version posted February 25, 2022. The copyright holder for this preprint (which was not certified by peer review) is the author/funder, who has granted bioRxiv a license to display the preprint in perpetuity. It is made available under aCC-BY-NC-ND 4.0 International license.

A phylogenetic tree was constructed using MEGAX based on the top 10 BLASTP hits of five neprosins from Nepenthes species (Fig. S2). Most of the hits were hypothetical, predicted, or uncharacterized proteins. BLASTP hits of NvNpr, NrNpr1, and NrNpr2 shared a C-terminal peptidase from Nepenthes alata (BAW35437.1). In addition to BAW35437.1, NrNpr2 found hits to another N. alata C-terminal peptidase (BAW35438.1). NaNpr1 and NaNpr2 BLASTP results contain carboxyl-terminal peptidase, putative metal tolerance protein 4-like, 3-methyl-2oxobutanoate hydroxymethyltransferase, and tRNA-splicing ligase. According to the phylogenetic tree, neprosins from $N$. rafflesiana, $N . \times$ ventrata, and C-terminal peptidase from N. alata shared a closer most recent common ancestor (MRCA) compared to N. ampullaria. Hence, neprosins from $N$. ampullaria are more distant in the evolutionary relationship than other Nepenthes species.

BLASTP search against the Arabidopsis thaliana amino acid sequences using Dicots Plaza 5.0 found a carboxyl-terminal peptidase (DUF239) (AT3G48230) and a putative NEPinteracting protein (AT5G19170) to be closest to NvNpr, NrNpr1, and NrNpr2 (Fig. S3). Meanwhile, NaNpr1 and NaNpr2 were closer to two tRNA-splicing ligases (DUF239) (AT5G56530 and AT1G55360) and a putative carboxyl-terminal peptidase (AT3G13510). Based on the phylogenetic trees generated using BLASTP and Arabidopsis hits, closely related amino acid sequences of neprosin were selected for multiple sequence alignment (MSA) using Clustal Omega (Fig. S4). The MSA was used for ConSurf analysis to determine functionally conserved amino acids in the neprosins (Fig. 2). Based on ConSurf results, the catalytic triad Ser-Asp-His of commonly found prolyl endopeptidases (MEROPS S9A family) was not found. Moreover, the motif of S9A (GGSXGGLL, X normally Asn or Ala), S9B (GWSYGGY), S9C (GGSYGG), and S9D (GGHSYGAFMT) were also not found in the amino acid sequences of neprosin. Hence, neprosin has been classified as family U74 (unknown catalytic type) in MEROPS. 
bioRxiv preprint doi: https://doi.org/10.1101/2022.02.22.481544; this version posted February 25, 2022. The copyright holder for this preprint (which was not certified by peer review) is the author/funder, who has granted bioRxiv a license to display the preprint in perpetuity. It is made available under aCC-BY-NC-ND 4.0 International license.

\subsection{Experimental quality neprosin models}

For structure prediction to unveil the catalytic mechanism of neprosin, NvNpr was chosen as a reference due to its established prolyl endopeptidase (PEP) activity (Rey et al. 2016). Another homolog from N. rafflesiana (NrNpr1) sharing 96\% sequence identity with NvNpr (Fig. 1) was included for comparative analysis. Due to the lack of a crystal structure in PDB with significant identity for homology modeling, we applied the two latest $a b$ initio methods, namely RoseTTAFold and AlphaFold2, to generate three-dimensional (3D) protein structures. The firstrank models with the highest confidence level were chosen from the five models generated for each method (Fig. 3). All neprosin models generated were globular proteins with secondary structures mainly comprising coils (38-44\%), followed by $\beta$-strands (32-34\%) and helices (912\%) (Table S1). The two antiparallel six- and seven-stranded $\beta$-sheets form an overall $\beta$ sandwich structure like that of glucanases. Notably, independently predicted high-quality neprosin models from both RoseTTAFold and AlphaFold2 showed very high structural similarities, especially in the $\beta$-sandwich structure (Fig. 3). RoseTTAFold and AlphaFold2 models of NvNpr can be structurally aligned for 239 amino acids with mTM-align pairwise TMscore as high as 0.919 and RMSD of $1.920 \AA$; whereas for NrNpr1 alignment of 322 amino acids, the pairwise TM-score was 0.899 with $2.435 \AA$ RMSD.

Based on the SWISS-MODEL protein model quality assessment (Table 1), Ramachandran favored in neprosin models generated by RoseTTAFold and AlphaFold2 were around $92-96 \%$. Ramachandran favored refers to the fraction of residues in favored regions of the Ramachandran plot, which is ideally $>98 \%$. AlphaFold 2 models were of higher quality based on the lower clashscores and MolProbity (a composite score of normalized all-atom clashscore, Ramachandran favored, and rotamer outlier). The clashscore is the number of serious steric overlaps (>0.4 $\AA$ ) per 1,000 atoms and should be ideally close to 0 (Chen et al. 2010). Meanwhile, the QMEANDisCo Global scores of AlphaFold2 models were also higher. Overall, AlphaFold2 
bioRxiv preprint doi: https://doi.org/10.1101/2022.02.22.481544; this version posted February 25, 2022. The copyright holder for this preprint (which was not certified by peer review) is the author/funder, who has granted bioRxiv a license to display the preprint in perpetuity. It is made available under aCC-BY-NC-ND 4.0 International license.

outperformed RoseTTAFold in generating near experimental quality neprosin models for further analysis.

Table 1. Quality assessment of the first-rank protein models generated by RoseTTAFold and AlphaFold2. Ramachandran favored (\%), clashscore, MolProbity score, and QMEANDisCo Global of the models were obtained from structure assessment of SWISS-MODEL. Confidence is assigned to RoseTTAFold models by Robetta server while pLDDT is provided as an output to models generated by AlphaFold2 with MMseqs2 via ColabFold.

\begin{tabular}{llcccccc}
\hline Method & Model & $\begin{array}{c}\text { Ramachandran } \\
\text { favored }(\%)\end{array}$ & Clashscore* & $\begin{array}{c}\text { MolProbity } \\
\text { score* }\end{array}$ & $\begin{array}{c}\text { QMEANDisCo } \\
\text { Global }\end{array}$ & Confidence & pLDDT \\
\hline RoseTTAFold & NvNpr & 95.60 & 172.97 & 3.00 & $0.61 \pm 0.05$ & 0.71 \\
& NrNpr1 & 92.66 & 185.39 & 3.19 & $0.81 \pm 0.05$ & 0.70 & \\
AlphaFold2 & NvNpr & 92.66 & 27.68 & 2.39 & $0.75 \pm 0.05$ & 91.2 \\
& NrNpr1 & 94.07 & 25.82 & 2.30 & $0.81 \pm 0.05$ & 91.6 \\
\hline
\end{tabular}

*Lower score indicates a higher quality

AlphaFold 2 models were of higher confidence based on a per-residue measure of local confidence with the overall predicted local distance difference test IDDT-C $\alpha$ (pLDDT) scores of over 90 . A reasonable model has a pLDDT score of 60 or greater, while scores above 80 are great models. Meanwhile, confidence scores of RoseTTAFold models ranged between 0.70 and 0.71 . Notably, most of the regions in neprosin models generated using AlphaFold2 showed pLDDT $>90$, which is expected to be highly accurate and suitable for applications such as characterizing binding sites (Jumper et al. 2021). There were several positions in the models where pLDDT <80 (Fig. 4). At amino acid position around $100^{\text {th }}$, there was a drop of pLDDT below 40 in both NvNpr and NrNpr1 models. Intriguingly, this position (excluding the signal peptide) matched to the second proposed start site of mature $\operatorname{NvNpr}$ (Fig. 1). The $90^{\text {th }}$ to $110^{\text {th }}$ amino acids of both NvNpr and NrNpr1 models correspond to the region of amino acids between Neprosin_AP and neprosin domains showed pLDDT $<50$, suggesting that this region could be unstructured (Fig. 4). Regions with pLDDT $<50$ often have a ribbon-like appearance and are disordered, either unstructured in physiological conditions or only structured as a part of a complex (Jumper et al. 2021). The disordered region of protein, also known as intrinsically disordered protein region 
bioRxiv preprint doi: https://doi.org/10.1101/2022.02.22 481544; this version posted February 25, 2022. The copyright holder for this preprint (which was not certified by peer review) is the author/funder, who has granted bioRxiv a license to display the preprint in perpetuity. It is made available under aCC-BY-NC-ND 4.0 International license.

(IDPR) provides conformational flexibility and structural dynamics that allows its protein to perform unorthodox activity that is impossible in ordered proteins (Uversky 2019). The IDPR between the Neprosin_AP and neprosin domains could act as a flexible linker that connects the two structured domains.

\subsection{Protein structural alignment revealed neprosin as a glutamic peptidase}

Neprosin protein models from AlphaFold2 were subjected to heuristic PDB search using DALI protein structure comparison server. Both NvNpr and NrNpr1 searches (Table 2) found hits to the crystal structure of scytalidoglutamic peptidase or scytalidopepsin B (SGP, PDB ID: 2ifw), which is the founding member of the peptidase family G1, so far found only in fungi. Apart from SGP, DALI search also found chain-B of aspergillopepsin II or aspergilloglutamic peptidase (AGP, PDB ID: 1y43-b) (Table 2).

Table 2. Results of DALI search hits in the PDB database. The Z-score, RMSD $(\AA)$, sequence identity, and average pairwise length, $\mathrm{L}_{\text {ali }}$ are assigned to each DALI search hit.

\begin{tabular}{lcccc}
\hline Attribute & \multicolumn{2}{c}{ NvNpr } & \multicolumn{2}{c}{ NrNpr1 } \\
\hline Hit & 2 ifw & $1 \mathrm{y} 43-\mathrm{b}$ & 2 ifw & $1 \mathrm{y} 43-\mathrm{b}$ \\
Z-score & 13.6 & 8.9 & 13.5 & 8.9 \\
RMSD $(\AA)$ & 2.7 & 3.2 & 2.7 & 3.3 \\
Sequence identity & 0.11 & 0.05 & 0.12 & 0.06 \\
Average pairwise length, $\mathrm{L}_{\text {ali }}$ & 175 & 149 & 173 & 152 \\
\hline
\end{tabular}

SGP and AGP are categorized as members of the glutamic peptidase family G1 in the MEROPS database. Root-mean-square-deviation (RMSD) is a common measurement used for the evaluation of structural similarity but is not used in the DALI scoring. DALI Z-score is a length-dependent rescaling of the collective score of distance matrix alignment and scoring function (Holm 2020). The higher Z-score shows higher structural similarity between the query and the PDB hits but cannot be used for interpreting homology, as sequence and functional conservation are needed to infer the evolutionary relationship. Holm et al. (2008) defines Z- 
bioRxiv preprint doi: https://doi.org/10.1101/2022.02.22 481544 this version posted February 25, 2022. The copyright holder for this preprint (which was not certified by peer review) is the author/funder, who has granted bioRxiv a license to display the preprint in perpetuity. It is made available under aCC-BY-NC-ND 4.0 International license.

scores above 2 as 'significant similarities' and correspond to similar folds. A 'strong match' requires either sequence identity $>20 \%$ or Z-score cutoff above $(n / 10)-4$ (where $n$ is the number of residues in query structure). The sequence similarities between $2 \mathrm{ifw}$ and $1 \mathrm{y} 43-\mathrm{b}$ with the neprosins were below 20\%, while the Z-score cutoffs for both NvNpr and NrNpr1 were 31.6 [(356/10)-4]. Hence, the hits to glutamic peptidases fall under 'significant similarities'.

NvNpr and NrNpr1 protein models superimposed with DALI hits of SGP (MEROPS ID: G01.001) and AGP (MEROPS ID: G01:002) crystal structures (Fig. S5) showed very high structural similarity with reported active cleft and catalytic dyad (Fujinaga et al. 2004; Pillai et al. 2007; Sasaki et al. 2004). Interestingly, the neprosin domain structure is very similar to the glucanase-like $\beta$-sandwich formed by the two seven-stranded antiparallel $\beta$-sheet as described in the eqolisin family or glutamic peptidases (G1). The structure of the neprosin domain resembles the active clefts of glutamic peptidases. This observation supports that neprosin domain is the catalytic domain with peptidase activity. The glutamic acid residues of the catalytic dyad were found to overlap at the corresponding sites in the active cleft (Fig. S5). Fujinaga et al. (2004) resolved the tertiary structure of SGP and proposed a hydrolytic mechanism whereby water is bound to Glu136 as the primary catalytic residue while Gln53 acts as a nucleophile after it is activated into hydroxide ion by Glu136 carboxylation. The side-chain amide of Gln53 provides electrophilic assistance for the formation of tetrahedral intermediate and oxyanion stabilization. Site-directed mutagenesis conducted on aspergilloglutamic peptidase (AGP) concurs with the proposed catalytic residues (Yabuki et al. 2004). Mutation of Gln133 (corresponding to Gln53 of SGP) resulted in a complete loss of function of enzymatic activity without changing the conformation of AGP. Furthermore, a Q133E/E219Q double mutant of AGP (Glu219 corresponds to Glu136 of SGP) did not mature via autoproteolysis upon incubation and thus showed no enzymatic activity (Yabuki et al. 2004). 
bioRxiv preprint doi: https://doi.org/10.1101/2022.02.22.481544; this version posted February 25, 2022. The copyright holder for this preprint (which was not certified by peer review) is the author/funder, who has granted bioRxiv a license to display the preprint in perpetuity. It is made available under aCC-BY-NC-ND 4.0 International license.

Later, Sasaki et al. (2005) proposed that catalytic glutamic acid of AGP acts as a general acid in the first phase of catalysis by donating $\mathrm{H}^{+}$ion to the carbonyl oxygen of scissile peptide bond of a substrate. A water molecule donates an $\mathrm{OH}^{-}$group to the carbonyl carbon to form a tetrahedral intermediate. The transition state of the substrate is stabilized by hydrogen bonding with the two catalytic residues. In the next phase, the protonated glutamic acid donates the $\mathrm{H}^{+}$ ion to the amide nitrogen atom of the scissile peptide bond, which causes the breakdown of tetrahedral intermediate and cleavage of the peptide bond.

Both proposed catalytic mechanisms of SGP and AGP suggest the glutamic acid of the catalytic dyad as the general acid that donates $\mathrm{H}^{+}$ion for the protonation of leaving-group nitrogen, which is an essential step for the hydrolysis of an amide (Fujinaga et al. 2004; Sasaki et al. 2005). Moreover, solvent kinetic isotope effects and the proton inventory studies by Kondo et al. (2010) also support the catalytic mechanism of SGP requires nucleophilic attack of water molecule activated by catalytic glutamic residue (Glu136). Meanwhile, the amino acid residue in the neprosin models that is superposed to the catalytic glutamine residue (Gln53 of SGP or Gln24 of AGP) is a glutamic acid (Glu164). Therefore, Glu164 and Glu273 (numbering in neprosin without signal peptide) were hypothesized as the catalytic dyad responsible for prolyl endopeptidase-like catalytic activity.

The two glutamic acid residues of the hypothetical catalytic dyad were highly conserved in the neprosin family according to the ConSurf analysis (Fig. 2). The glutamic acid residues (Glu188 and Glu297 for full-length sequences; Glu164 and Glu273 in sequences without the signal peptide) were conserved in all nine sequences. According to InterPro, these two glutamic acid residues were highly conserved in the neprosin domain (PF03080), with conservation of $>0.8$ in representative proteomes 15 of 427 sequences and $>0.6$ in representative proteomes 35 of 2,067 sequences (Fig. S6). High conversation of these glutamic acids suggests their important roles in maintaining the structure or function of the neprosin domain. 


\subsection{Neprosin belongs to the newly found glutamic peptidase family G3}

Based on all the characteristics described above, we found a glutamic peptidase with a catalytic dyad comprising two glutamic acids and post-proline cleaving activity from MEROPS peptidase family G3. The sole member of the newly found family G3, strawberry mottle virus (SMoV) glutamic peptidase (MER1365461) has a catalytic dyad of Glu1192 and Glu1274 as proven by the mutagenesis study (Mann et al. 2019). Furthermore, this peptidase appears to have a preference to cleave after proline residue without the limitation of substrate size like that reported in neprosin by Schräder et al. (2017). For instance, SMoV cleaves after proline in a big polyprotein (1,691 amino acids) to form products of peptide-Pro1101+Ala-peptide and peptidePro1444+Lys-peptide (Mann et al. 2019). The SMoV peptidase unit ranges from amino acid $1,102^{\text {nd }}$ to $1,335^{\text {th }}$ (234 amino acids), which was modelled using AlphaFold2. The superimposition of this peptidase unit with NvNpr shows catalytic dyad of this family G3 glutamic peptidase (Glu 91 and Glu 173, numbering in peptidase unit) superposed the hypothetical catalytic dyad of Glu164 and Glu273 in NvNpr and NrNpr1 (Fig. S7).

\subsection{Neprosin maturation via proteolysis provides substrate access to the active site}

Mass spectrometry (MS) analysis by Rey et al. (2016) found that native NvNpr from the pitcher fluids contains mainly the neprosin domain (PF03080) with an estimated molecular mass of 28.9 $\mathrm{kDa}$. This suggests that neprosin maturation requires proteolysis, which is supported by the observation that recombinant $\mathrm{NvNpr}$ required one-week incubation in $\mathrm{pH} 2.5$ buffer for autolytic activation (Schräder et al. 2017). Similarly, mature SGP (260 residues) and AGP (282 residues) have only 206 and 212 amino acids, respectively. The autoproteolytic maturation of AGP has been described by Inoue et al. (1991). The AGP proenzyme comprises 264 amino acids after Nterminal signal peptide (18 residues) removal. The pre-pro sequence (41 residues) for the 
bioRxiv preprint doi: https://doi.org/10.1101/2022.02.22 481544 this version posted February 25, 2022. The copyright holder for this preprint (which was not certified by peer review) is the author/funder, who has granted bioRxiv a license to display the preprint in perpetuity. It is made available under aCC-BY-NC-ND 4.0 International license.

inhibition and thermal stabilization of the zymogen will be removed in acidic conditions (Inoue et al. 1991; Kubota et al. 2005). Lastly, the 11-residue intervening peptide is removed via autoproteolysis to form the mature AGP (212 residues) with light chain (39 residues) and heavy chain (173 residues) that are bound non-covalently.

Another known similarity between neprosin and glutamic peptidases is their optimal working $\mathrm{pH}$. A circular dichroism (CD) spectrum of AGP zymogen dialyzed against buffer at $\mathrm{pH}$ 5.25 was identical to that of the full-length recombinant zymogen, while the dialysis of AGP zymogen against $\mathrm{pH} 3.5$ buffer yielded a spectrum identical to that of mature AGP that could digest hemoglobin under acidic ( $\mathrm{pH}$ 2.0) conditions (Huang et al. 2007). Similarly, SGP maintained its structure and enzymatic activity in $\mathrm{pH}$ range from 2 to 7 but denatured at $\mathrm{pH}>8$ (Kondo et al. 2010). Meanwhile, NvNpr showed maximum activity at $\mathrm{pH} 2.5$ and active up to pH 5 with near-zero activity at pH 8 (Rey et al. 2016).

Sasaki et al. (2012) proposed a mechanism of autoproteolysis according to the crystal structure of a dimeric AGP. The C-terminal of the light chain of one AGP is found in the active cleft of another AGP like a substrate. This autoproteolytic mechanism could be possible in neprosin as the full-length $\mathrm{NvNpr}$ (380 residues) is $42 \mathrm{kDa}$, about $\sim 12 \mathrm{kDa}$ heavier than native and active recombinant neprosins with two proposed start sites (Fig. 1). The second start site in the IDPR after a proline residue is more probably for the mature neprosin because no peptide fragment before the "cleaving after P" site was observed in the MS analysis of neprosin by Rey et al. (2016) due to its post-proline cleaving activity (Schräder et al. (2017). The predicted molecular mass for the mature recombinant neprosin (252 amino acids) is $27.6 \mathrm{kDa}$, which is lighter than the native neprosin with glycosylation.

To investigate further on neprosin maturation, the start site of mature NrNpr1 was deduced from the sequence alignment with the proposed start sites of mature NvNpr (Fig. 1). The flexible IDPR could play role in neprosin activation via proteolysis by allowing protease binding 
bioRxiv preprint doi: https://doi.org/10.1101/2022.02.22.481544; this version posted February 25, 2022. The copyright holder for this preprint (which was not certified by peer review) is the author/funder, who has granted bioRxiv a license to display the preprint in perpetuity. It is made available under aCC-BY-NC-ND 4.0 International license.

or conformational changes of neprosins. In AGP, autoproteolysis via the binding of one proenzyme to the active cleft of another resulted in enzyme activation (Sasaki et al. 2012). Such autoproteolysis in neprosin proenzyme could be possible since the IDPR is positioned near to the active cleft with high structural similarity to AGP (Fig. 4 \& S5). This will need to be experimental validated by crystallography study of neprosins.

Predicted mature protein models of NvNpr (m-NvNpr) and NrNpr1 (m-NrNpr1) after the removal of the neprosin activation domain were generated by AlphaFold 2 with very high pLDDT scores of 94.4 and 95.1, respectively. Notably, the mature neprosin models showed very high structural similarities to the crystal structures of AGP-chain B and SGP, as well as the AlphaFold2 model of the SMoV peptidase unit (Fig. S8). Based on mTM-align pairwise structure alignment, the TM-scores between mature neprosin models ( $\mathrm{m}-\mathrm{NvNpr}$ and $\mathrm{m}-\mathrm{NrNpr} 1)$ and the glutamic peptidases (AGP-chain B, SGP, and SMoV) were above 0.6 despite that the percentage identity was less than $13 \%$. At a TM-score cut-off of 0.5 , the P-value is $5.5 \times 10^{-7}$ (1.8 million protein pairs needed to achieve by random chance) according to Xu et al. (2010). This means that structural similarities between glutamic peptidases and mature neprosin were highly significant.

CASTp 3.0 web server was used to predict empty concavities (pockets) to which solvent can gain access for different neprosin protein models (Fig. 5). In both NvNpr and NrNpr1, the largest pockets were observed in the putative active clefts only in the mature neprosin models. Hence, we hypothesized that the removal of the neprosin activation domain exposes the putative cleft for the activation of neprosin, allowing access for substrate catalysis. A possible substrate of neprosin is $\alpha$ I-gliadin, which is resistant to gastrointestinal digestion while transglutaminase (TG2) deamination confers enhanced immunogenicity in triggering celiac disease by binding to HLA-DQ2 in the intestine (Kim et al. 2004). To investigate whether neprosins can bind $\alpha \mathrm{I}-$ gliadin, docking of neprosin models with $\alpha$ I-gliadin was conducted using PatchDock. Protein docking with $\alpha$ I-gliadin found no solution in the putative active cleft of neprosin with the 
bioRxiv preprint doi: https://doi.org/10.1101/2022.02.22 481544 this version posted February 25, 2022. The copyright holder for this preprint (which was not certified by peer review) is the author/funder, who has granted bioRxiv a license to display the preprint in perpetuity. It is made available under aCC-BY-NC-ND 4.0 International license.

presence of neprosin activation domain. The first docking solutions with high docking scores of 7,752 and 7,956 were found for both mature neprosin models of NvNpr and NrNpr1, respectively, with a good fit of $\alpha$ I-gliadin substrate inside the putative active clefts (Fig. 6). The atomic contact energy (ACE) of mNrNpr1 and mNvNpr were -193.76 and -182.07 , respectively. Furthermore, the approximate interface area of the docking complex with NvNpr and NrNpr1 were 992.60 and 1049.40, respectively. This supports that both mature mNvNpr and mNrNpr1 could bind $\alpha \mathrm{I}$-gliadin for hydrolysis. The molecular dynamics simulation using CABS-flex 2.0 showed that the putative catalytic dyad (Glu60 and Glu169, numbering in mature neprosin) in both m-NvNpr and m-NrNpr1 were in a stable region with low RMSF (Table 3, Fig. S9).

Table 3. RMSF $(\AA)$ of the putative catalytic residues in mature neprosin models (m-NvNpr and $\mathrm{m}-\mathrm{NrNpr} 1)$. Residue fluctuation, $\operatorname{RMSF}(\AA)$ values are extracted from residue fluctuation profile output of molecular dynamics stimulation by CABS-flex 2.0.

\begin{tabular}{llc}
\hline Models & Putative catalytic residue & RMSF $(\AA)$ \\
\hline m-NvNpr & Glu60 & 0.262 \\
& Glu169 & 0.373 \\
m-NrNpr1 & Glu60 & 0.181 \\
& Glu169 & 0.274 \\
\hline
\end{tabular}

\subsection{A proposed model of neprosin regulation and catalytic mechanism}

Based on previous literature and the hypothesis that neprosin belongs to the glutamic peptidase family G3 with autoproteolytic maturation, we proposed a general model on the regulation of neprosin based on NvNpr (Fig. 7). Neprosin and other proteases have been shown to be expressed in the pitcher tissue even before pitcher opening (Goh et al. 2020). Neprosin proteins undergo post-translational modifications, such as glycosylation and the removal of signal peptide before being secreted into the pitcher fluid as a proenzyme upon pitcher opening. Their expression can be induced by ammonium, chitin, and protein from prey in the pitcher fluid (Lee et al. 2016; Wan Zakaria et al. 2019; Zulkapli et al. 2021). The presence of prey (ammonium, chitin, or protein) in the pitcher fluid triggers the acidification of pitcher fluid (Bazile et al. 2015; Lee et al. 2016; 
bioRxiv preprint doi: https://doi.org/10.1101/2022.02.22 481544 this version posted February 25, 2022. The copyright holder for this preprint (which was not certified by peer review) is the author/funder, who has granted bioRxiv a license to display the preprint in perpetuity. It is made available under aCC-BY-NC-ND 4.0 International license.

Saganová et al. 2018), resulting in the activation of neprosin via autoproteolysis or hydrolysis by other proteases. During proteolysis, hydrolysis at the disordered region between Neprosin_AP and neprosin domains in the proenzyme forms the mature neprosin with only the neprosin domain. The mature neprosin structure showed accessible putative active cleft for substrate binding.

The proposed catalytic neprosin domain with prolyl endopeptidase activity (Rey et al. 2016) resembles glucanase-like $\beta$-sandwich, which comprises two seven-stranded antiparallel $\beta$ sheet, unique to the glutamic peptidase family. The catalytic dyad of two glutamic acids with post-proline cleaving activity strongly supports that neprosin belongs to the MEROPS peptidase family G3. To date, no proteolysis mechanism has been described that involves a catalytic dyad of two glutamic acids shown by Mann et al. (2019) to be responsible for the post-proline cleaving activity of SMoV peptidase. Here, we propose a possible catalytic mechanism based on the catalytic dyad of AGP shown by Sasaki et al. (2005) with the glutamine (Gln) residue replaced by glutamic acid (Glu) in neprosin (Fig. 8). Since glutamic acid is often found in protein active binding sites, the hydroxyl group of Glu, despite being negatively charged, could function similarly to that of the Gln amide sidechain in providing electrophilic assistance and oxyanion stabilization to the tetrahedral intermediate state of the peptide bond. Glu169 in mature neprosin could act as a general acid during the first phase of proteolysis by donating a proton to the oxygen of the carbonyl group of the scissile peptide bond. Then, Glu169 acts as a general base to activate a water molecule that carries out a nucleophilic attack on the carbonyl carbon atom of the scissile peptide bond. The water molecule with a hydrogen bond formed with the hydroxyl group of Glu60 donates an $\mathrm{OH}$ - group to the carbonyl carbon of the scissile peptide bond to form a tetrahedral intermediate. The process of electron transfer is aided by another water molecule held by hydrogen bonding with Glu60 and Glu169. The transition state of the scissile peptide bond is stabilized by hydrogen bonding with the two catalytic Glu residues. In the next phase, the 
bioRxiv preprint doi: https://doi org/10.1101/2022.02.22 481544: this version posted February 25,2022 . The copyright holder for this preprint (which was not certified by peer review) is the author/funder, who has granted bioRxiv a license to display the preprint in perpetuity. It is made available under aCC-BY-NC-ND 4.0 International license.

protonated Glu169 donates the proton to nitrogen of the amide group of the peptide bond. Finally, the protonation of leaving-group nitrogen triggers the breakdown of tetrahedral intermediate and causes peptide bond hydrolysis.

\section{Conclusion}

In this study, in silico structure-function analysis of the neprosin family provided evidence for the classification of neprosins as glutamic peptidases with prolyl endopeptidase activity. It also revealed the putative regulation and catalytic mechanism of neprosin as depicted in Figs. 7 and 8. This is supported by structural similarity, autoproteolysis activation in low $\mathrm{pH}$ conditions, and the presence of glutamic acid residues in the putative active cleft. Moreover, the catalytic dyad of family G3 with post-proline cleaving activity (Glu1192 and Glu1274 in full-length SMoV peptidase) superposed to that of the hypothetical catalytic dyad of NvNpr (Glu60 and Glu169). Further validation experiments such as crystallography studies and the expression of recombinant neprosin with site-directed mutagenesis of the two glutamic acid residues will ascertain these catalytic residues in the neprosin family. It will also be interesting to study the functional divergence of neprosin family in other plant species.

\section{Ethics approval and consent to participate}

Not applicable.

\section{Human and animal rights}

No Animals/Humans were used for studies that are the basis of this research.

\section{Consent for publication}

Not applicable.

\section{Availability of data and materials}


bioRxiv preprint doi: https://doi org/10.1101/2022 0222.481544 : this version posted February 25,2022 . The copyright holder for this preprint (which was not certified by peer review) is the author/funder, who has granted bioRxiv a license to display the preprint in perpetuity. It is made available under aCC-BY-NC-ND 4.0 International license.

All PDB files of protein structures and docking described in this manuscript can be accessed on Figshare (https://doi.org/10.6084/m9.figshare.19187252).

\section{Declaration of competing interest}

The authors declare that they have no known competing financial interests or personal relationships that could have appeared to influence the work reported in this paper.

\section{Acknowledgments}

This work was supported by the Malaysian Ministry of Higher Education Fundamental Research

Grant Scheme (FRGS/1/2019/STG05/UKM/02/10) and Universiti Kebangsaan Malaysia Research University Grant (DIP-2020-005). The group also acknowledges the great effort of ColabFold team in making the structural prediction via AlphaFold2 and RoseTTAFold accessible.

\section{Author contributions}

H-H.G. conceived the study and obtained funding. T.Y.T. and A.B. performed the analysis. T.Y.T. and H-H.G. wrote the manuscript. A.B.R and C.L.N. reviewed the manuscript. All authors approved the final manuscript.

\section{Supportive/supplementary material}

Supplementary material is available on the publisher's website along with the published article. All PDB files of protein structures and docking described in this manuscript can be accessed on Figshare (https://doi.org/10.6084/m9.figshare.19187252). 
bioRxiv preprint doi: https://doi.org/10.1101/2022.02.22.481544; this version posted February 25, 2022. The copyright holder for this preprint (which was not certified by peer review) is the author/funder, who has granted bioRxiv a license to display the preprint in perpetuity. It is made available under aCC-BY-NC-ND 4.0 International license.

\section{List of Figures}

Figure 1. Multiple sequence alignment of neprosins identified from $N . \times$ ventrata $(\mathrm{NvNpr}$, MER0351045), N. ampullaria (NaNpr1 and NaNpr2, GenBank: ARA959695.1 and GenBank: ARA9596.1), and N. rafflesiana ( $\mathrm{NrNpr} 1$ and $\mathrm{NrNpr}$ ) showing the signal peptide, functional domains, and disulfide bond pairing of cysteine [C] residues. The percentage identity matrix of full-length neprosin amino acid sequences is depicted. The numbers on the left corresponds to the positions of residues for each domain. Theoretical molecular weight (MW) and isoelectric point (pI) are shown for sequences excluding the signal peptide. Two putative start sites for mature enzyme of NvNpr (Rey et al. 2016) are indicated by orange boxes. The pI for mature NvNpr (m-NvNpr) from the first start site $(28.95 \mathrm{kDa})$ was predicted as 4.63 compared to $\mathrm{m}$ NvNpr from the second start site $(27.55 \mathrm{kDa})$ of 4.30 .

Figure 2. Conservation and functionality of amino acids in the multiple sequence alignment of neprosin family with NvNpr as a query in ConSurf analysis. The orange boxes highlight the highly conserved glutamic acid (E) residues.

Figure 3. The first-rank models with the best quality generated by AlphaFold 2 with MMseqs 2 (bronze) and RoseTTAFold (cyan) for NvNpr (top) and NrNprl (bottom) superimposed using 'Matchmaker' function in ChimeraX.

Figure 4. The first-rank AlphaFold 2 models of NvNpr (yellow) and NrNpr1 (blue) superimposed using ChimeraX 'Matchmaker' function with respective pLDDT plots. The inset with blue border shows NrNpr1 model visualized using Jmol FirstGlance and colored according to pLDDT score.

Figure 5. Predicted binding pockets in neprosin proenzymes ( $\mathrm{NvNpr}$ and $\mathrm{NrNpr} 1$ ) and mature neprosin ( $\mathrm{m}-\mathrm{NvNpr}$ and $\mathrm{m}-\mathrm{NrNpr} 1)$ models. The red pockets have the largest solvent-accessible volume, followed by yellow and blue pockets. Richard's solvent-accessible volumes are annotated next to the pockets with respective colored font.

Figure 6. Top docking solutions of mature neprosins from $N . \times$ ventrata $(\mathrm{m}-\mathrm{NvNpr})$ and $\mathrm{N}$. rafflesiana (m-NrNpr1) with deaminated $\alpha$ I-gliadin using PatchDock. Left docking models are in ribbon style while models on the right are surface displayed.

Figure 7. Proposed regulatory mechanism of neprosin protein in the Nepenthes pitcher. Theoretical molecular weight $(\mathrm{kDa})$ and isoelectric point $(\mathrm{pI})$ of $\mathrm{NvNpr}$ are shown. Mature neprosin is based on the second putative start site.

Figure 8. Proposed catalytic mechanism of neprosin inside the active site of substrate binding cleft. Dotted lines indicate hydrogen bonds. Circled numbers represent sequential reactions.

\section{List of Tables}

Table 1. Quality assessment of first rank protein models generated using RoseTTAFold and AlphaFold2. Ramachandran favored (\%), MolProbity score, QMEANDisCo Global, and clashscore of the models were obtained from structure assessment of SWISS-MODEL. Confidence is assigned to RoseTTAFold models by Robetta server, while pLDDT is provided as an output to models generated by AlphaFold2 with MMseqs 2 by ColabFold. 
bioRxiv preprint doi: https://doi.org/10.1101/2022.02.22.481544; this version posted February 25, 2022. The copyright holder for this preprint (which was not certified by peer review) is the author/funder, who has granted bioRxiv a license to display the preprint in perpetuity. It is made available under aCC-BY-NC-ND 4.0 International license.

Table 2. Results of DALI search hits in the PDB database. The Z-score, RMSD ( $)$, sequence identity, and average pairwise length, Lali are assigned to each DALI search hit.

Table 3. RMSF $(\AA)$ of the putative catalytic residues in mature neprosin models (m-NvNpr and m-NrNpr1). Residue fluctuation, $\operatorname{RMSF}(\AA)$ values are extracted from residue fluctuation profile output of molecular dynamics stimulation by CABS-flex 2.0.

\section{List of Supplementary Table}

Table S1. Secondary structures in the predicted models of NvNpr and NrNpr1 based on Jmol FirstGlance analysis.

\section{List of Supplementary Figures}

Figure S1. Summary workflow of in silico analysis on neprosin amino acid sequences.

Figure S2. Phylogenetic tree of neprosin amino acid sequences with respective top 10 BLASTP hits from NCBI nr database, constructed using MEGAX package with Maximum Likelihood of 500 bootstraps. The black boxes indicate the neprosin query sequences for BLASTP searches.

Figure S3. Phylogenetic tree of neprosins with BLASTP hits against the Arabidopsis thaliana genome sequence database using Dicots PLAZA 5.0.

Figure S4. Multiple sequence alignment of neprosins and their closely related amino acid sequences of BLASTP hits against NCBI $\mathrm{nr}$ ( $N$. alata C-terminal peptidases: BAW35438.1 and BAW35437.1) and Arabidopsis sequence (AT5G19170 and AT3G48230) using Clustal Omega. The neprosin activation and neprosin domains are highlighted in red and blue box, respectively. Figure S5. Superimposition of scytalidoglutamic peptidase (SGP, 2ifw) and aspergilloglutamic peptidase (AGP, 1y43) crystal structures with the AlphaFold2 neprosin models of $N$. $\times$ ventrata (NvNpr) and $N$. rafflesiana $(\mathrm{NrNpr} 1)$.

Figure S6. Representative proteomes 15 (RP15) and representative proteomes 35 (RP35) of neprosin domain (PF03080). The glutamic acid residues of putative catalytic dyad are conserved in $>0.8$ of 427 sequences in RP15 and $>0.6$ of 2,067 sequences in RP35.

Figure S7. Supeimposition of AlphaFold 2 models of strawberry mottle virus (SMoV) glutamic peptidase unit with neprosins from $N$. $\times$ ventrata $(\mathrm{NvNpr})$ and $N$. rafflesiana $(\mathrm{NrNpr} 1)$.

Figure S8. Superimposition and mTM-align pairwise alignment of crystal structures of scytalidoglutamic peptidase (SGP, PDB id: $2 \mathrm{ifw}$ ) and aspergilloglutamic peptidase (AGP, PDB id: $1 \mathrm{y} 43-\mathrm{B})$ with the AlphaFold 2 models of $N$. $\times$ ventrata $(\mathrm{m}-\mathrm{NvNpr}), N$. rafflesiana (m-NrNpr1), and strawberry mottle virus glutamic peptidase (SMoV, MER1365461). Pairwise TM-score, RMSD, and alignment length $\left(\mathrm{L}_{\mathrm{ali}}\right)$ were obtained from structural alignment using $\mathrm{mTM}$-align, 
bioRxiv preprint doi: https://doi.org/10.1101/2022.02.22.481544; this version posted February 25, 2022. The copyright holder for this preprint (which was not certified by peer review) is the author/funder, who has granted bioRxiv a license to display the preprint in perpetuity. It is made available under aCC-BY-NC-ND 4.0 International license.

whereas sequence identity (\%ID) was based on pairwise sequence alignment using Clustal Omega.

Figure S9. Output of molecular dynamics stimulation of m-NvNpr (top) and m-NrNpr1 (bottom) by CABS-flex 2.0. (A) three-dimensional visualization of 10 models. (B) Residue fluctuation profile (RMSF) plots.

\section{References}

Amagase, S. 1972. Digestive enzymes in insectivorous plants. 3. Acid proteases in the genus Nepenthes and Drosera peltata. J Biochem 72(1): 73-81.

Amagase, S., Nakayama, S. \& Tsugita, A. 1969. Acid protease in Nepenthes. II. Study on the specificity of nepenthesin. J Biochem 66(4): 431-439.

Ashkenazy, H., Abadi, S., Martz, E., Chay, O., Mayrose, I., Pupko, T. \& Ben-Tal, N. 2016. ConSurf 2016: an improved methodology to estimate and visualize evolutionary conservation in macromolecules. Nucleic Acids Res 44(W1): W344-350.

Baek, M., Dimaio, F., Anishchenko, I., Dauparas, J., Ovchinnikov, S., Lee, G. R., Wang, J., Cong, Q., Kinch, L. N., Schaeffer, R. D., Millán, C., Park, H., Adams, C., Glassman, C. R., Degiovanni, A., Pereira, J. H., Rodrigues, A. V., Van Dijk, A. A., Ebrecht, A. C., Opperman, D. J., Sagmeister, T., Buhlheller, C., Pavkov-Keller, T., Rathinaswamy, M. K., Dalwadi, U., Yip, C. K., Burke, J. E., Garcia, K. C., Grishin, N. V., Adams, P. D., Read, R. J. \& Baker, D. 2021. Accurate prediction of protein structures and interactions using a three-track neural network. Science 373(6557): 871-876.

Barrett, A. J. 2001. Proteases. Curr Protoc Protein Sci Chapter 21: Unit 21.21.

Bazile, V., Le Moguédec, G., Marshall, D. J. \& Gaume, L. 2015. Fluid physico-chemical properties influence capture and diet in Nepenthes pitcher plants. Annals of Botany 115(4): 705-716.

Buch, F., Kaman, W. E., Bikker, F. J., Yilamujiang, A. \& Mithöfer, A. 2015. Nepenthesin protease activity indicates digestive fluid dynamics in carnivorous nepenthes plants. PLoS One 10(3): e0118853.

Chen, V. B., Arendall, W. B., 3rd, Headd, J. J., Keedy, D. A., Immormino, R. M., Kapral, G. J., Murray, L. W., Richardson, J. S. \& Richardson, D. C. 2010. MolProbity: all-atom structure validation for macromolecular crystallography. Acta crystallographica. Section D, Biological crystallography 66(Pt 1): 12-21.

Clarke, S. \& Robinson, A. 2018. Carnivorous Plants: Physiology, ecology, and evolution. Ellison, A. \& Adamec, L. Oxford: Oxford University Press.

Cornish-Bowden, A. 2014. Current IUBMB recommendations on enzyme nomenclature and kinetics. Perspectives in Science 1(1): 74-87.

Dong, R., Pan, S., Peng, Z., Zhang, Y. \& Yang, J. 2018. mTM-align: a server for fast protein structure database search and multiple protein structure alignment. Nucleic Acids Res 46(W1): W380-w386.

Ferrè, F. \& Clote, P. 2006. DiANNA 1.1: An extension of the DiANNA web server for ternary cysteine classification. Nucleic Acids Research 34(WEB. SERV. ISS.): 182-185.

Fujinaga, M., Cherney, M. M., Oyama, H., Oda, K. \& James, M. N. 2004. The molecular structure and catalytic mechanism of a novel carboxyl peptidase from Scytalidium lignicolum. Proc Natl Acad Sci U S A 101(10): 3364-3369.

Goh, H. H., Baharin, A., Mohd Salleh, F. I., Ravee, R., Wan Zakaria, W. N. A. \& Mohd Noor, N. 2020. Transcriptome-wide shift from photosynthesis and energy metabolism upon 
bioRxiv preprint doi: https://doi.org/10.1101/2022.02.22.481544; this version posted February 25, 2022. The copyright holder for this preprint (which was not certified by peer review) is the author/funder, who has granted bioRxiv a license to display the preprint in perpetuity. It is made available under aCC-BY-NC-ND 4.0 International license.

endogenous fluid protein depletion in young Nepenthes ampullaria pitchers. Scientific Reports 10(1): 1-17.

Holm, L. 2020. Using Dali for protein structure comparison. Methods Mol Biol 2112: 29-42.

Holm, L., Kääriäinen, S., Rosenström, P. \& Schenkel, A. 2008. Searching protein structure databases with DaliLite v.3. Bioinformatics (Oxford, England) 24(23): 2780-2781.

Huang, X. P., Yabuki, Y., Kojima, M., Inoue, H. \& Takahashi, K. 2007. Activation profiles of the zymogen of aspergilloglutamic peptidase. Biol Chem 388(1): 129-133.

Inoue, H., Kimura, T., Makabe, O. \& Takahashi, K. 1991. The gene and deduced protein sequences of the zymogen of Aspergillus niger acid proteinase A. J Biol Chem 266(29): 19484-19489.

Jumper, J., Evans, R., Pritzel, A., Green, T., Figurnov, M., Ronneberger, O., Tunyasuvunakool, K., Bates, R., Žídek, A., Potapenko, A., Bridgland, A., Meyer, C., Kohl, S. a. A., Ballard, A. J., Cowie, A., Romera-Paredes, B., Nikolov, S., Jain, R., Adler, J., Back, T., Petersen, S., Reiman, D., Clancy, E., Zielinski, M., Steinegger, M., Pacholska, M., Berghammer, T., Bodenstein, S., Silver, D., Vinyals, O., Senior, A. W., Kavukcuoglu, K., Kohli, P. \& Hassabis, D. 2021. Highly accurate protein structure prediction with AlphaFold. Nature 596(7873): 583-589.

Kim, C.-Y., Quarsten, H., Bergseng, E., Khosla, C. \& Sollid, L. M. 2004. Structural basis for HLA-DQ2-mediated presentation of gluten epitopes in celiac disease. Proceedings of the National Academy of Sciences of the United States of America 101(12): 4175-4179.

Kondo, M. Y., Okamoto, D. N., Santos, J. a. N., Juliano, M. A., Oda, K., Pillai, B., James, M. N. G., Juliano, L. \& Gouvea, I. E. 2010. Studies on the catalytic mechanism of a glutamic peptidase. The Journal of biological chemistry 285(28): 21437-21445.

Kubota, K., Nishii, W., Kojima, M. \& Takahashi, K. 2005. Specific inhibition and stabilization of aspergilloglutamic peptidase by the propeptide. Identification of critical sequences and residues in the propeptide. J Biol Chem 280(2): 999-1006.

Kuriata, A., Gierut, A. M., Oleniecki, T., Ciemny, Maciej p., Kolinski, A., Kurcinski, M. \& Kmiecik, S. 2018. CABS-flex 2.0: a web server for fast simulations of flexibility of protein structures. Nucleic Acids Research 46(W1): W338-W343.

Lee, L., Zhang, Y., Ozar, B., Sensen, C. W. \& Schriemer, D. C. 2016. Carnivorous nutrition in pitcher plants (Nepenthes spp.) via an unusual complement of endogenous enzymes. $J$ Proteome Res 15(9): 3108-3117.

Madeira, F., Park, Y. M., Lee, J., Buso, N., Gur, T., Madhusoodanan, N., Basutkar, P., Tivey, A. R. N., Potter, S. C., Finn, R. D. \& Lopez, R. 2019. The EMBL-EBI search and sequence analysis tools APIs in 2019. Nucleic Acids Research 47(1): 636-641.

Mann, K. S., Chisholm, J. \& Sanfaçon, H. 2019. Strawberry Mottle Virus (Family Secoviridae, Order Picornavirales) Encodes a Novel Glutamic Protease To Process the RNA2 Polyprotein at Two Cleavage Sites. Journal of virology 93(5): e01679-01618.

Mirdita, M., Ovchinnikov, S. \& Steinegger, M. 2021. ColabFold - Making protein folding accessible to all.

Mistry, J., Chuguransky, S., Williams, L., Qureshi, M., Salazar, G. A., Sonnhammer, E. L. L., Tosatto, S. C. E., Paladin, L., Raj, S., Richardson, L. J., Finn, R. D. \& Bateman, A. 2021. Pfam: The protein families database in 2021. Nucleic Acids Research 49(D1): D412-D419.

Nielsen, H. 2017. Predicting Secretory Proteins with SignalP. Methods Mol Biol 1611: 59-73.

Pettersen, E. F., Goddard, T. D., Huang, C. C., Meng, E. C., Couch, G. S., Croll, T. I., Morris, J. H. \& Ferrin, T. E. 2021. UCSF ChimeraX: Structure visualization for researchers, educators, and developers. Protein Science 30(1): 70-82. 
bioRxiv preprint doi: https://doi.org/10.1101/2022.02.22.481544; this version posted February 25, 2022. The copyright holder for this

Pillai, B., Cherney, M. M., Hiraga, K., Takada, K., Oda, K. \& James, M. N. 2007. Crystal structure of scytalidoglutamic peptidase with its first potent inhibitor provides insights into substrate specificity and catalysis. J Mol Biol 365(2): 343-361.

Ravee, R., Baharin, A., Cho, W. T., Ting, T. Y. \& Goh, H. H. 2021. Protease activity is maintained in Nepenthes ampullaria digestive fluids depleted of endogenous proteins with compositional changes. Physiologia Plantarum 173(4): 1967-1978.

Ravee, R., Salleh, F. M. \& Goh, H. H. 2018. Discovery of digestive enzymes in carnivorous plants with focus on proteases. PeerJ (6): e4914.

Rawlings, N. D., Barrett, A. J., Thomas, P. D., Huang, X., Bateman, A. \& Finn, R. D. 2018. The MEROPS database of proteolytic enzymes, their substrates and inhibitors in 2017 and a comparison with peptidases in the PANTHER database. Nucleic Acids Research 46(1): 624-632.

Rey, M., Yang, M., Lee, L., Zhang, Y., Sheff, J. G., Sensen, C. W., Mrazek, H., Halada, P., Man, P., Mccarville, J. L., Verdu, E. F. \& Schriemer, D. C. 2016. Addressing proteolytic efficiency in enzymatic degradation therapy for celiac disease. Scientific Reports 6: 30980.

Rosli, M. A. F., Mediani, A., Azizan, K. A., Baharum, S. N. \& Goh, H. H. 2021. UPLC-TOFMS/MS-based metabolomics analysis reveals species-specific metabolite compositions in pitchers of Nepenthes ampullaria, Nepenthes rafflesiana, and their hybrid Nepenthes $\times$ hookeriana. Frontiers in Plant Science 12:

Rottloff, S., Miguel, S., Biteau, F., Nisse, E., Hammann, P., Kuhn, L., Chicher, J., Bazile, V., Gaume, L., Mignard, B., Hehn, A. \& Bourgaud, F. 2016. Proteome analysis of digestive fluids in Nepenthes pitchers. Annals of Botany 117(3): 479-495.

Saganová, M., Bokor, B., Stolárik, T. \& Pavlovič, A. 2018. Regulation of enzyme activities in carnivorous pitcher plants of the genus Nepenthes. Planta 248(2): 451-464.

Sasaki, H., Kojima, M., Sawano, Y., Kubota, K., Suganuma, M., Muramatsu, T., Takahashi, K. \& Tanokura, M. 2005. A proposed catalytic mechanism of aspergilloglutamic peptidase from Aspergillus niger. Proceedings of The Japan Academy Series B-physical and Biological Sciences - PROC JPN ACAD B 81: 441-446.

Sasaki, H., Nakagawa, A., Muramatsu, T., Suganuma, M., Sawano, Y., Kojima, M., Kubota, K., Takahashi, K. \& Tanokura, M. 2004. The three-dimensional structure of aspergilloglutamic peptidase from Aspergillus niger. Proceedings of the Japan Academy. Series B, Physical and Biological Sciences 80(9): 435-438.

Schneidman-Duhovny, D., Inbar, Y., Nussinov, R. \& Wolfson, H. J. 2005. PatchDock and SymmDock: Servers for rigid and symmetric docking. Nucleic Acids Research 33(SUPPL. 2): 363-367.

Schräder, C. U., Lee, L., Rey, M., Sarpe, V., Man, P., Sharma, S., Zabrouskov, V., Larsen, B. $\&$ Schriemer, D. C. 2017. Neprosin, a selective prolyl endoprotease for bottom-up proteomics and histone mapping. Molecular and Cellular Proteomics 16(6): 1162-1171.

Tian, W., Chen, C., Lei, X., Zhao, J. \& Liang, J. 2018. CASTp 3.0: computed atlas of surface topography of proteins. Nucleic Acids Res 46(W1): W363-w367.

Uversky, V. N. 2019. Intrinsically disordered proteins and their "mysterious" (meta)physics. Frontiers in Physics 7: 10.

Van bel, M., Silvestri, F., Weitz, E. M., Kreft, L., Botzki, A., Coppens, F. \& Vandepoele, K. 2022. PLAZA 5.0: extending the scope and power of comparative and functional genomics in plants. Nucleic Acids Research 50(D1): D1468-D1474.

Wan Zakaria, W.-N.-A., Loke, K.-K., Zulkapli, M.-M. I., Mohd Salleh, F.-I., Goh, H.-H. \& Mohd Noor, N. 2016. RNA-seq analysis of Nepenthes ampullaria. Frontiers in Plant Science 6: 1229-1229. 
bioRxiv preprint doi: https://doi.org/10.1101/2022.02.22 481544 this version posted February 25, 2022. The copyright holder for this preprint (which was not certified by peer review) is the author/funder, who has granted bioRxiv a license to display the preprint in perpetuity. It is made available under aCC-BY-NC-ND 4.0 International license.

Wan Zakaria, W. N. A., Aizat, W. M., Goh, H. H. \& Mohd Noor, N. 2019. Protein replenishment in pitcher fluids of Nepenthes $\times$ ventrata revealed by quantitative proteomics (SWATH-MS) informed by transcriptomics. Journal of Plant Research 132(5): 681-694.

Wan Zakaria, W. N. A., Aizat, W. M., Goh, H. H. \& Noor, N. M. 2018. Proteomic analysis of pitcher fluid from Nepenthes $\times$ ventrata. Data in Brief 17: 517-519.

Waterhouse, A., Bertoni, M., Bienert, S., Studer, G., Tauriello, G., Gumienny, R., Heer, F. T., De Beer, T. a. P., Rempfer, C., Bordoli, L., Lepore, R. \& Schwede, T. 2018. SWISSMODEL: Homology modelling of protein structures and complexes. Nucleic Acids Research 46(1): 296-303.

$\mathrm{Xu}$, J. \& Zhang, Y. 2010. How significant is a protein structure similarity with TM-score $=0.5$ ? Bioinformatics 26(7): 889-895.

Yabuki, Y., Kubota, K., Kojima, M., Inoue, H. \& Takahashi, K. 2004. Identification of a glutamine residue essential for catalytic activity of aspergilloglutamic peptidase by sitedirected mutagenesis. FEBS Lett 569(1-3): 161-164.

Zulkapli, M. M., Ab Ghani, N. S., Ting, T. Y., Aizat, W. M. \& Goh, H. H. 2021. Transcriptomic and proteomic analyses of Nepenthes ampullaria and Nepenthes rafflesiana reveal parental molecular expression in the pitchers of their hybrid, Nepenthes $\times$ hookeriana. Frontiers in Plant Science 11: 625507.

Zulkapli, M. M., Rosli, M. a. F., Salleh, F. I. M., Mohd Noor, N., Aizat, W. M. \& Goh, H. H. 2017. Iso-Seq analysis of Nepenthes ampullaria, Nepenthes rafflesiana and Nepenthes $\times$ hookeriana for hybridisation study in pitcher plants. Genomics Data 12: 130-131. 


\section{Graphical Abstract}

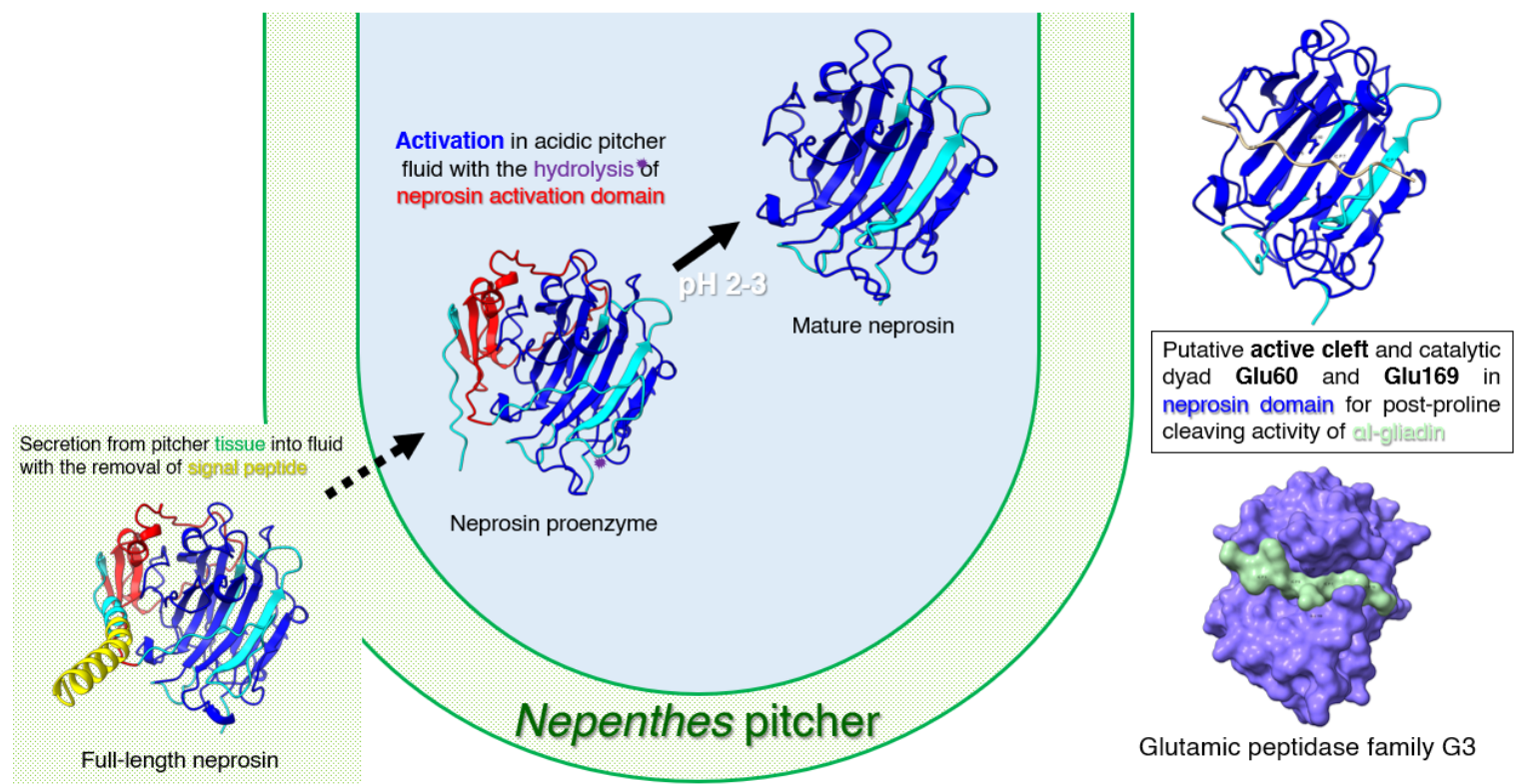




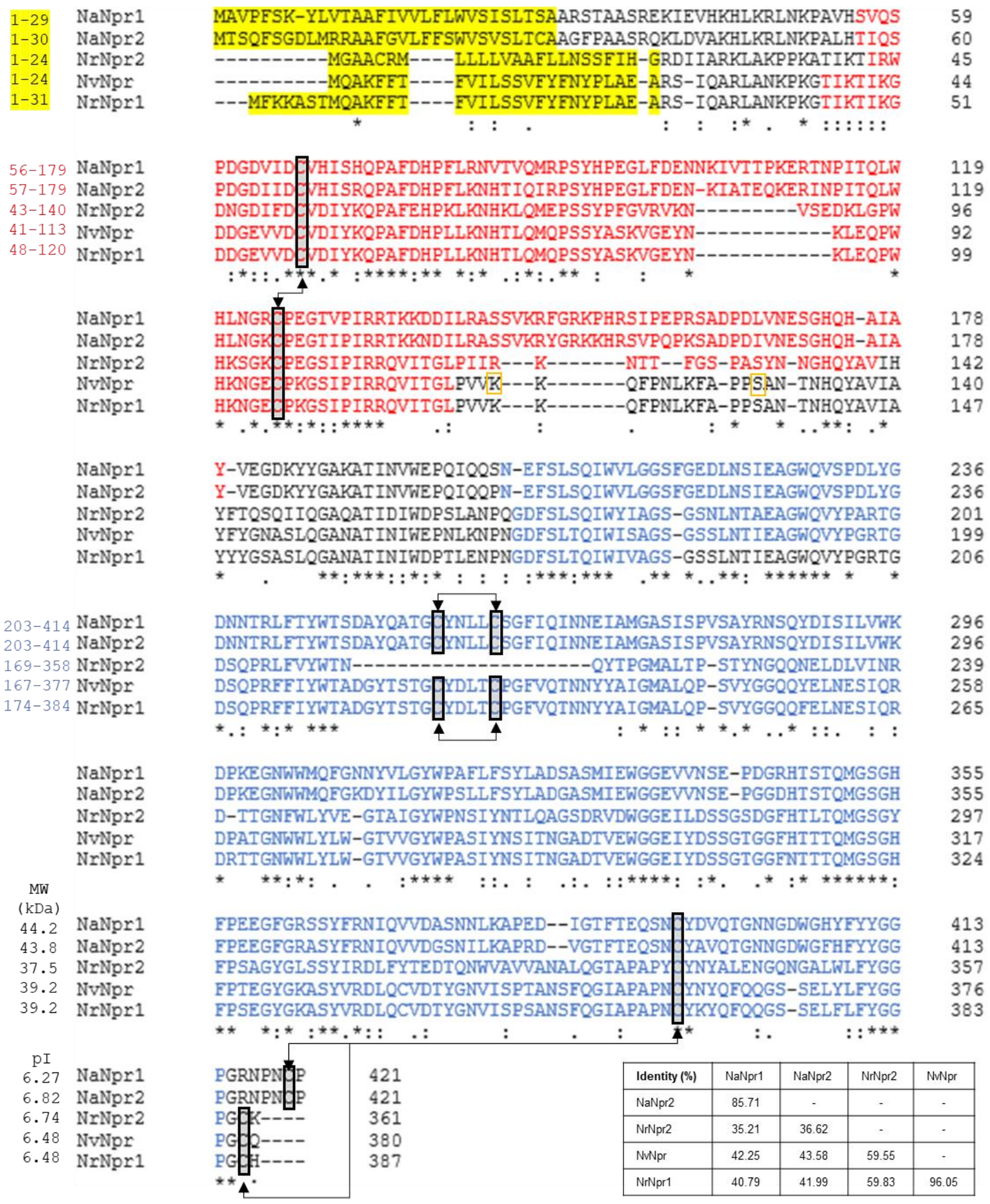

Signal peptide Neprosin activation domain (PF14365)/Neprosin_propep (IPR025521) Neprosin domain (PF03080) Disulfide bond

Figure 1. Multiple sequence alignment of neprosins identified from $N$. $\times$ ventrata (NvNpr, MER0351045), N. ampullaria (NaNpr1 and NaNpr2, GenBank: ARA959695.1 and GenBank: ARA9596.1), and N. rafflesiana (NrNpr1 and NrNpr2) showing the signal peptide, functional domains, and disulfide bond pairing of cysteine $[\mathrm{C}]$ residues. The percentage identity matrix of full-length neprosin amino acid sequences is depicted. The numbers on the left corresponds to the positions of residues for each domain. Theoretical molecular weight (MW) and isoelectric point (pI) are shown for sequences excluding the signal peptide. Two putative start sites for mature enzyme of NvNpr (Rey et al. 2016) are indicated by orange boxes. The $\mathrm{pI}$ for mature $\mathrm{NvNpr}(\mathrm{m}-\mathrm{NvNpr})$ from the first start site $(28.95 \mathrm{kDa})$ was predicted as 4.63 compared to $\mathrm{m}-\mathrm{NvNpr}$ from the second start site $(27.55 \mathrm{kDa})$ of 4.30 . 


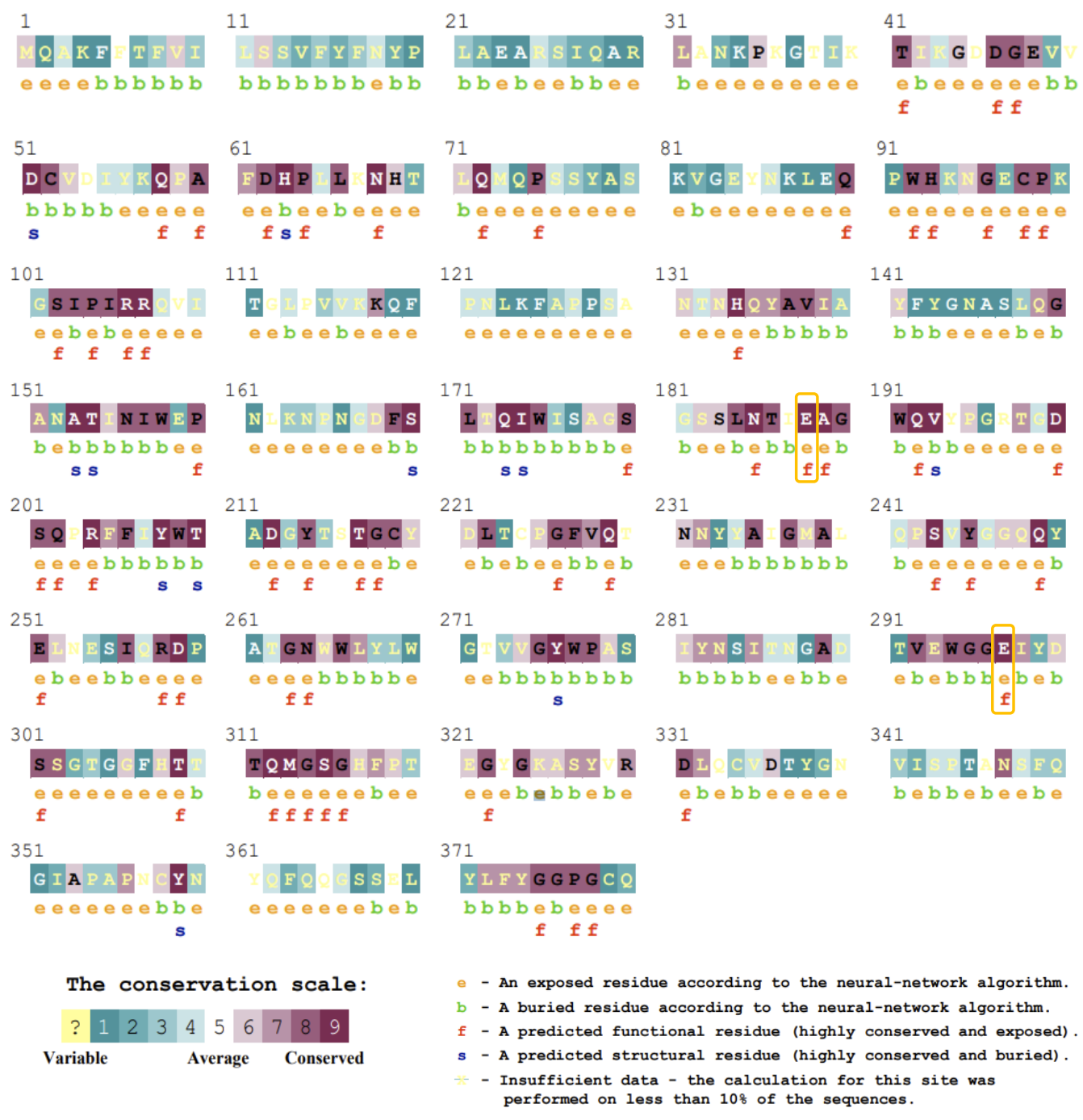

Figure 2. Conservation and functionality of amino acids in the multiple sequence alignment of neprosin family with $\mathrm{NvNpr}$ as a query in ConSurf analysis. The orange boxes highlight the highly conserved glutamic acid (E) residues. 

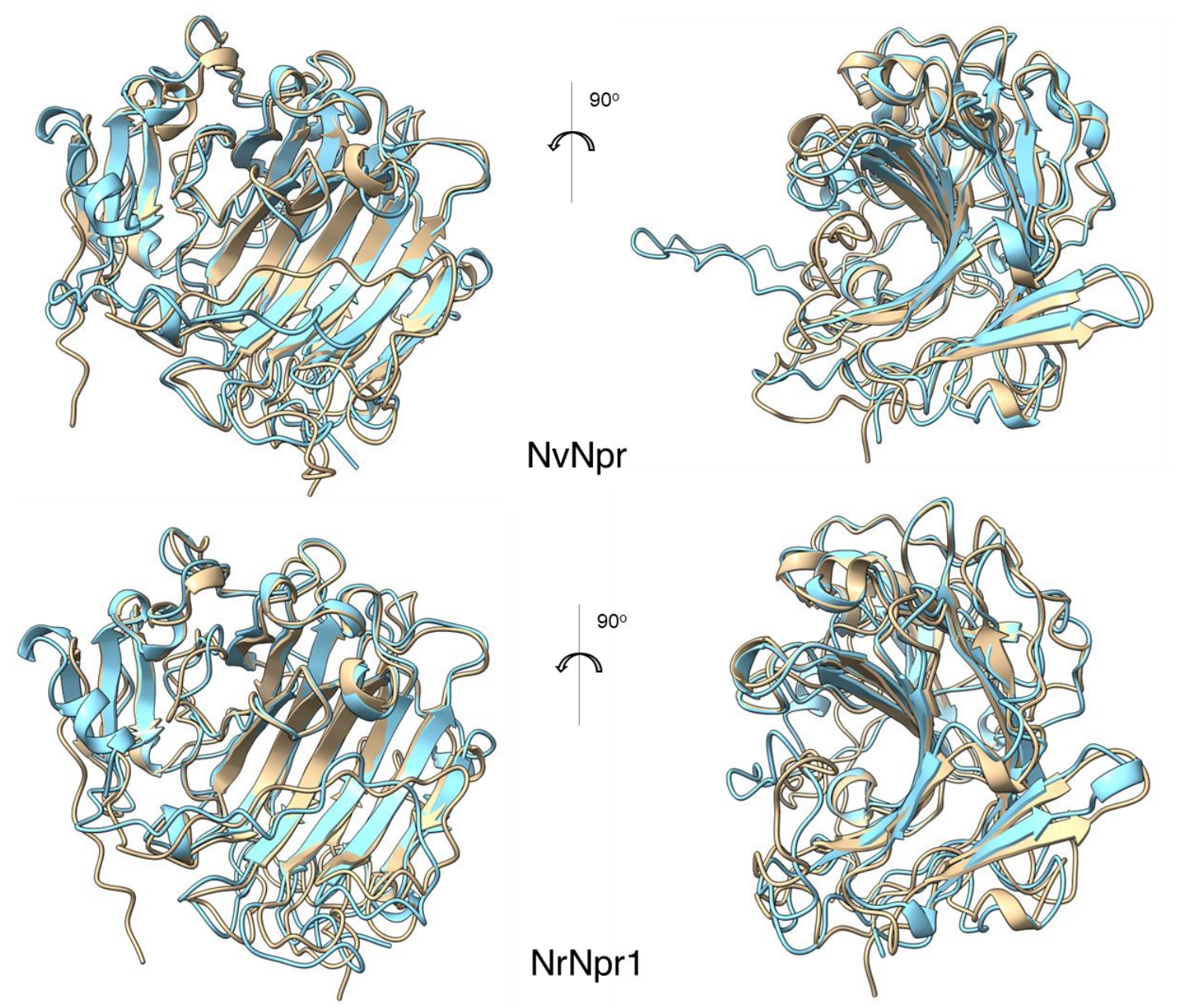

Figure 3. The first-rank models with the best quality generated by AlphaFold 2 with MMseqs2 (bronze) and RoseTTAFold (cyan) for NvNpr (top) and NrNpr1 (bottom) superimposed using 'Matchmaker' function in ChimeraX. 

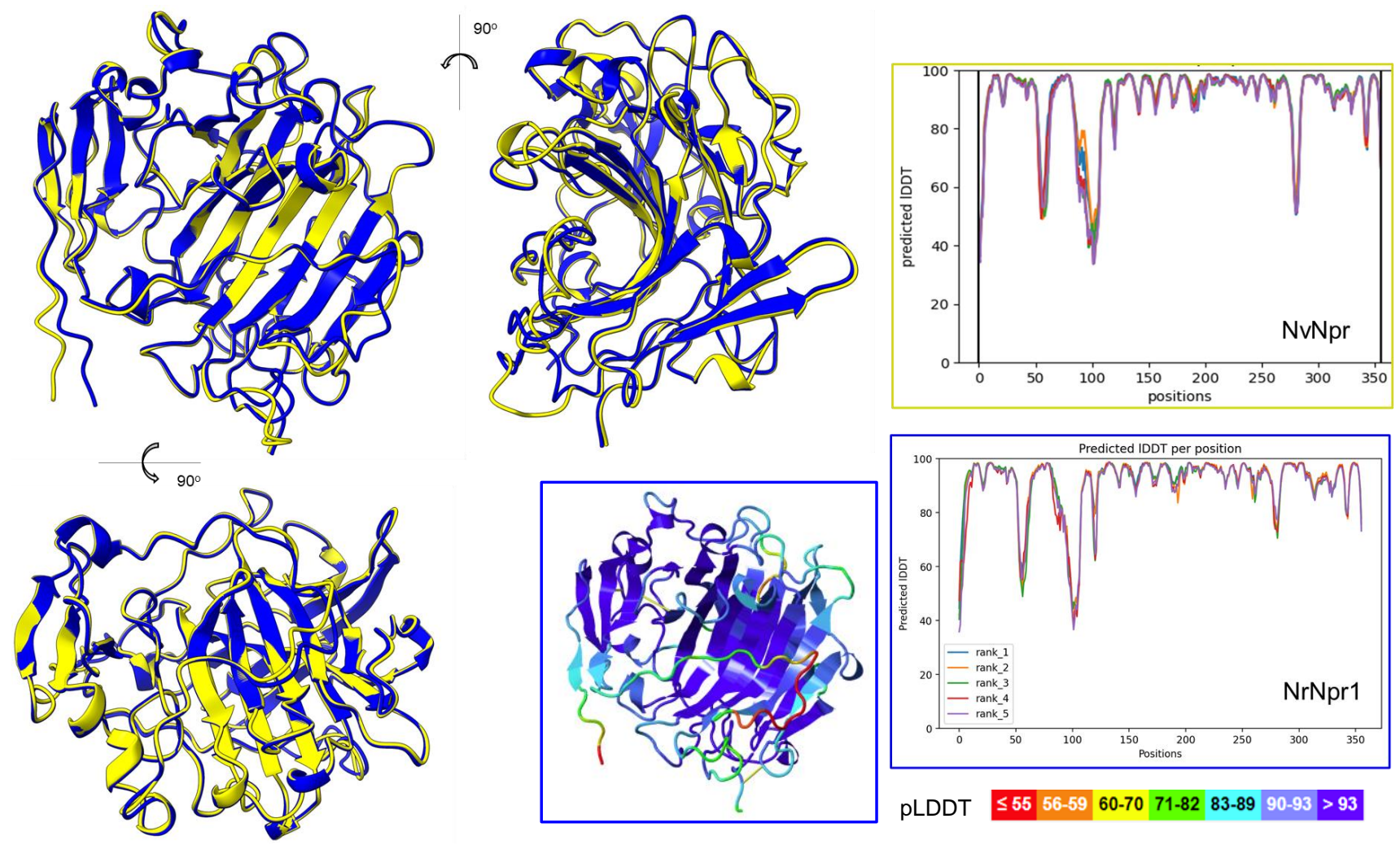

Figure 4. The first-rank AlphaFold 2 models of NvNpr (yellow) and NrNpr1 (blue) superimposed using ChimeraX 'Matchmaker' function with respective pLDDT plots. The inset with blue border shows NrNpr1 model visualized using Jmol FirstGlance and colored according to pLDDT score. 


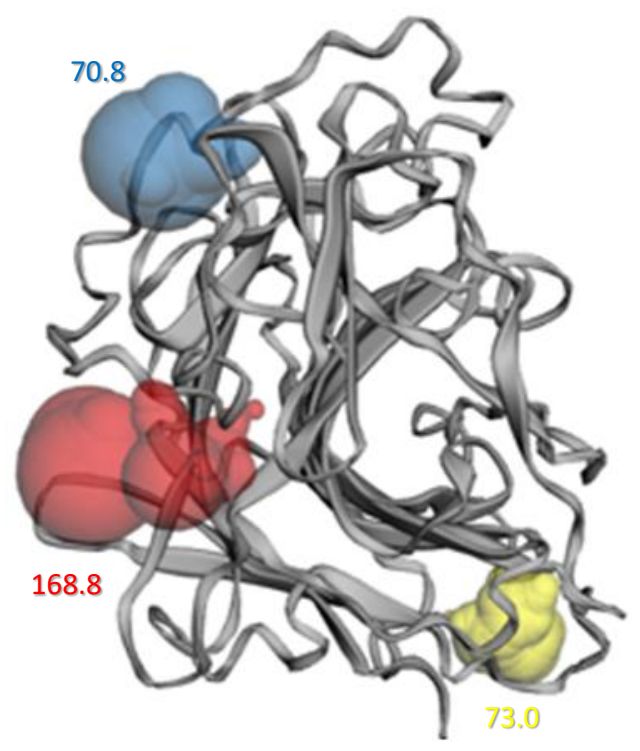

NvNpr1

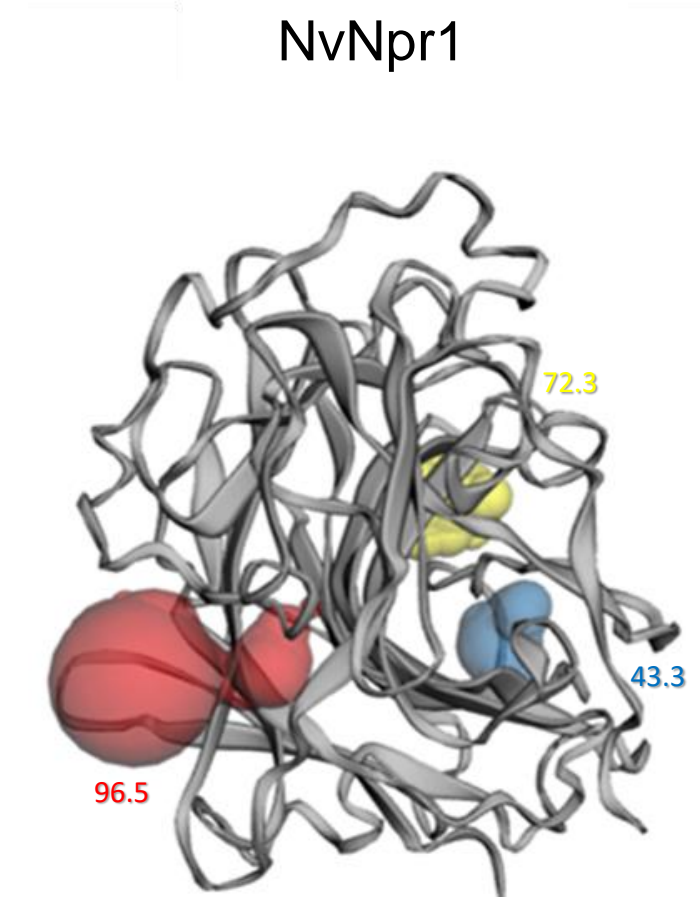

NrNpr1

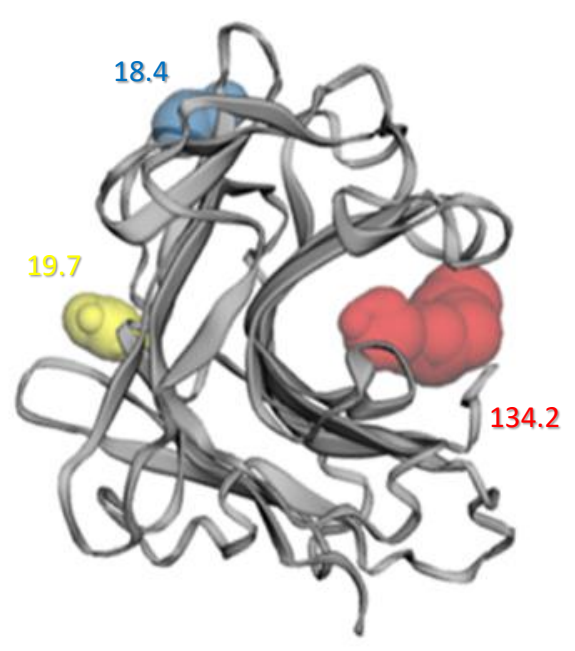

$\mathrm{m}-\mathrm{NvNpr}$



m-NrNpr1

Figure 5. Predicted binding pockets in neprosin proenzymes (NvNpr and $\mathrm{NrNpr} 1)$ and mature neprosin ( $\mathrm{m}-\mathrm{NvNpr}$ and $\mathrm{m}-\mathrm{NrNpr} 1)$ models. The red pockets have the largest solvent-accessible volume, followed by yellow and blue pockets. Richard's solventaccessible volumes are annotated next to the pockets with respective colored font. 


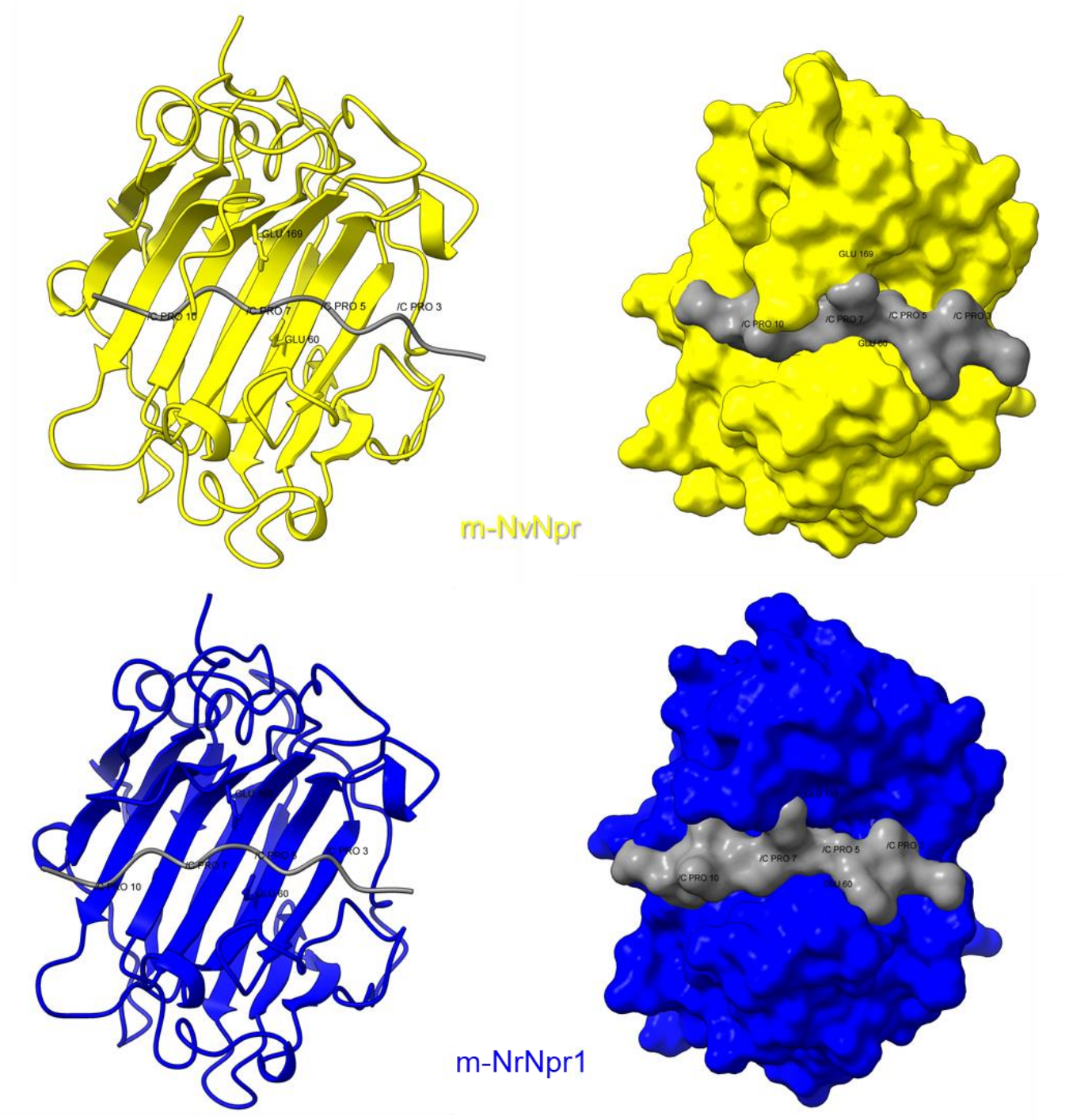

Figure 6. Top docking solutions of mature neprosins from $N . \times$ ventrata $(\mathrm{m}-\mathrm{NvNpr})$ and N. rafflesiana (m-NrNpr1) with deaminated al-gliadin using PatchDock. Left docking models are in ribbon style while models on the right are surface displayed. 




Figure 7. Proposed regulatory mechanism of neprosin protein in the Nepenthes pitcher. Theoretical molecular weight $(\mathrm{kDa})$ and isoelectric point $(\mathrm{pI})$ of NvNpr are shown. Mature neprosin is based on the second putative start site. 

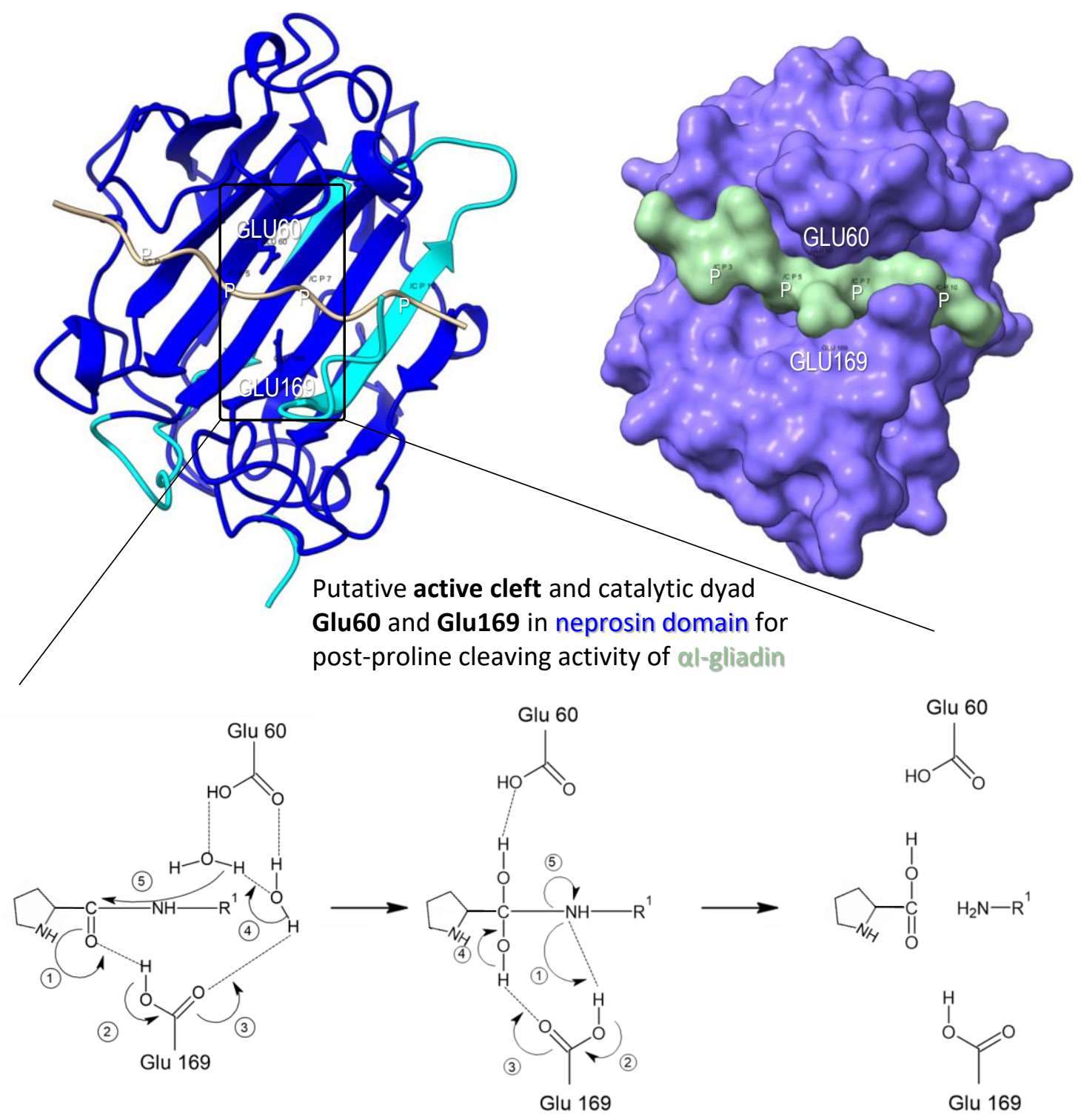

Figure 8. Proposed catalytic mechanism of neprosin inside the active site of substrate binding cleft. Dotted lines indicate hydrogen bonds. Numbers in circle represents sequential reactions. 